\title{
State and Right-Wing Populism: Analysis on the Kemenko Polhukam RI Persuasion Approach in Responding the Wave of " 212 " Movement
}

\author{
Dinda Rizkimawati \\ London School of Public Relations Jakarta \\ Email: dindarizkimawati59@gmail.com \\ Indra Kusumawardhana \\ Universitas Pertamina, Jakarta \\ Email: indra.kusumawardhana@universitaspertamina.ac.id
}

\begin{abstract}
Basuki Tjahaja Purnama's blasphemy case reaped various reactions and criticisms. In the "Action of Defending Islam 212", where Muslims in Indonesia expressed their anger, the masses demanded that religious blasphemers be brought to justice. It caused a series of demonstrations in Indonesia and instability in their domestic security, especially Jakarta as the capital city. This movement was widely known as the wave of rightwing populism in Indonesia. To respond to an extreme right-wing political movement in Indonesian society, the Coordinating Ministry for Political, Legal, and Security made efforts to persuade the community after the movement. This effort was significant in managing the widening of the narrative and reminding those who used the approach anchor base or key people and communities to help spread the message.
\end{abstract}

Keywords: Right-Wing Populism, 212 Movement, KEMENKOPOLHUKAM, Persuasion, Indonesia

\begin{abstract}
Abstrak
Kasus penistaan agama Basuki Tjahaja Purnama menuai berbagai reaksi dan kritik. Dalam "Aksi Bela Islam 212", di mana umat Islam di Indonesia mengungkapkan kemarahan mereka, massa menuntut agar para penoda agama diadili. Hal itu menyebabkan serangkaian demonstrasi di Indonesia
\end{abstract}


dan ketidakstabilan keamanan dalam negeri mereka, terutama Jakarta sebagai ibu kota. Gerakan ini dikenal luas sebagai gelombang populisme sayap kanan di Indonesia. Untuk menanggapi gerakan politik sayap kanan yang ekstrim di masyarakat Indonesia, Kementerian Koordinator Bidang Politik, Hukum, dan Keamanan melakukan upaya untuk membujuk masyarakat pasca gerakan. Upaya ini signifikan dalam mengelola pelebaran narasi dan mengingatkan mereka yang menggunakan pendekatan anchor base atau orang-orang dan komunitas kunci untuk membantu menyebarkan pesan.

Kata Kunci: Populisme Sayap Kanan, Gerakan 212, KEMENKOPOLHUKAM, Persuasi, Indonesia

\section{INTRODUCTION}

In the era of globalization and industrial communication 4.0 , the role of public relations is increasingly significant. Communication is critical for political activity. For instance, political actors need strategic communication for maintaining power interaction among them and their relations with the public. Nowadays, the elite and the public can interact through existing media channels. They can exchange information and aspirations directly through social media - such as Facebook, Twitter, or Instagram. All those media for sending messages to the people is essential for people's voices or aspirations to achieve political interests.

In Indonesia, the recent political event is the perfect example. The right-wing political movement rose during the 2017 DKI Jakarta regional head election through a series of demonstrations. The wave of people mobilization was built upon the exchange of information through social media.

This demonstration was triggered by Basuki Tjahaja Purnama (Ahok) as the Governor of DKI Jakarta Province speech in Kepulauan Seribu. He mentioned, "Jadi jangan percaya sama orang, kan bisa saja dalam hati kecil bapak ibu enggak bisa pilih saya ya kan? dibohongi pakai Surah Al-Maidah 51, macammacam itu. Itu hak bapakibu ya. Jadi kalau bapak-ibu perasaan enggak bisa kepilih nih, karena saya takut masuk neraka karena dibodohin gitu ya, enggak apa-apa," (Perjalanan 
Kasus Al Maidah 51 hingga Ahok Divonis 2 Tahun Penjara:

Okezone Megapolitan, n.d.).

"In your deepest heart, you may want to vote for me. Don't be fooled by Surah Al-Maidah 51. If you do and are afraid to go to hell because of voting for me, it's alright. It's your choice."

Many Indonesian Islamic communities reacted to that statement. They condemned the Governor of DKI Jakarta for committing blasphemy.

The movement to seek justice for Ahok's words began with mass mobilization to stage demonstrations. One of them is called Islamic Defense Actions (Aksi Bela Islam) at the end of 2016. The activity stole the attention of Indonesian society nationally. The " 212 " demonstration occurred on December 2, 2016, in Jakarta, Indonesia (Tirto: 27.02.2019).

The Islamic Defense Actions (IDA) commanded by the Islamic Defenders Front (FPI). To symbolize the protest, they created unique numbers for the taglines, such as $1410,411,212,112,212$ (Reunion), 313, and 55 (Republika: 10.05.2017). Each demonstration activity was focusing on echoing the mass invitation to join the IDA. It took place on December 2, 2016, which became 212, at the National Monument (Monas). The "212" demonstration caused traumatic effects related to the 1998 riots on the Indonesian community (BBC Indonesia: 01.12.2016). This activity also received attention from various parties because of President Jokowi, who previously was unable to accept representatives of 411 and 212 demonstrators (BBC Indonesia: 02.12.2016).

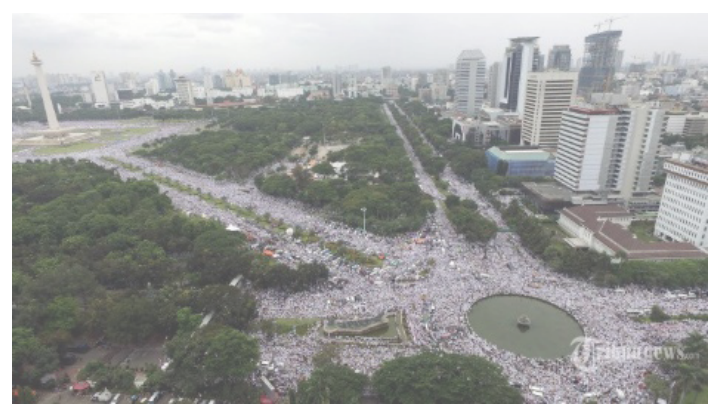

Figure 1. Display of Participants in the Defend Islam Action December 2, 2016 (https://bangka.tribunnews.com/2016/12/04/mengharukan-inilahkisah-pengalaman-wartawati-non-muslim-saat-liput-aksi-damai-212) 
When looking at the activities of Islamic defense actions carried out by FPI, the 212 Defend Islam Action call was not the only voiced agenda. The initial call agreed by this movement was to defend the Koran. Still, the action participants were not thoroughly carried out because this action also led to calls such as rejecting kafir or infidel leaders and choosing Muslim leaders (Kusumo \& Hurriyah: 2019, 97-109). Based on the notion of populist waves, John Judis stated that populist activities have massive 'political logic,' where people protest against the ruling elite due to a lack of trust (Judis, 2016: 50). The people feel that these elites no longer pay attention to the ideals of a nation and ignore what they understand to be a common constitution. These mass associations are eventually mobilized by the support bases and create a political identity according to the beliefs of the majority of the supporting bases.

Based on the understanding conveyed by Judis, the " 212 " movement is a part of rightwing populism in Indonesia. This movement talked about the issue of identity politics that prioritizes majority religious politics.

To respond to this scaremongering development, the Indo- nesian government should have a political communication strategy to ease the turmoil within their society. In this case, the government should develop the exact political communication efforts needed by emphasizing, educating, and persuading the public. It is essential to improve the government's image and reputation, build good socialization bridges, and forge trust between stakeholders in society.

In this context, the emergence of a wave of right-wing populism in Indonesia after the "212" movement during the governor elections in DKI Jakarta is a crucial issue nationally. The Indonesian President, as Head of Government, state leader, and commander in chief, must determine various kinds of decisions or policies that are acceptable to all levels of society. It made the President of Indonesia act quickly to communicate with the public to navigate the condition.

One of the government instruments is the ministries, which assist the President's duties as Head of Government. In Indonesia, the ministry in charge of leading a political-security situation is the Coordinating Ministry for Political, Legal, and Security Affairs (abbreviated Kemenko Polhukam $\mathrm{RI})$. 
Kemenko Polhukam RI is responsible for coordinating interrelated ministries under their authority, gathering information for the president regarding issues relating to security and legal issues, and being part of the president's official information funnel to the broader community regarding the problems.

During the specific political challenge, such as the wave of right-wing populism, these tasks were essential and vital to build and maintain mutual understanding between organizations with stakeholders and the public. The Kemeko Polhukam RI should support three issues-reputation, image, and communication with the public. This paper captures that to study the Indonesian government's persuasion through the Kemenko Polhukam RI for managing the "212" wave of right populism.

From those backgrounds, the authors initiate a research question: How did Kemenko Polhukam RI persuade the Indonesian people to manage the wave of right-wing populism after 212? As a case study, the authors utilize persuasion theory for analyzing this phenomenon. The analysis was based on primary data collection by conducting semi- structured or focused interviews with purposive informants.

The results of this study illustrate that Kemenko Polhukam RI developed a specific approach for overcoming the situation. The persuasive strategy is supported by choosing crucial persons and specific communities as communicators in conveying messages. Moreover, based on the analysis, the Kemenko Polhukam RI persuasion approach focused on the central route. They spread every update to the public, both from anti-government groups. Kemenko Polhukam RI aimed to provide official information collaborate with the key figures and the community. By providing ongoing counter-information, the public can compare the report and its credibility.

\section{Theoretical Framework}

According to Michel Hasting (Hastings et al., 2013: 9) denotes,

"Populism is a political style which is a source for change based on the systematic use of rhetorical appeal to the people."

The use of rhetoric in right-wing populism has an intersection with left-wing populism as a benchmark in formulating political rhetoric. The confluence lies in the resistance to the status quo and foreign powers, 
while the basis is not anti-capitalism but in the framing of discourses on "national values."

According to Muhtadi (2019), there are three definitions of populism, which can create a crisis. First, if there is a crisis in the economic sector, a recession will lead to poverty, unemployment, unequal growth, the impact of globalization, and the exploitation of natural resources. Inequality in society has become a modality for some parties to narrate political rhetoric that leads to claims of populism. Second, there has been sharp criticism over the failure of representative democracy. Third, through the existing economic inequality coupled with the imbalance of democratic promises, it is profitable for populist leaders to start their political rhetoric (Muhtadi, 2019: 5). Based on the explanation given, the action to defend Islam at Monas (Monumen Nasional) on December 2, 2016, has become an identity politics movement that prioritizes the majority religion to move the masses. This wave becomes a current resistance to the status quo or the current situation by providing rhetoric and discourse conveyed through the demonstrations. The action of defending Islam which has been carried out seven times and is accompanied by reunions carried out by its alumni, has tighter nuances of practical political movements.

Persuasion is a process of influencing a person's attitudes, beliefs, values, or behavior. Actions of persuasion refer to three possibilities: strengthening opinions, ideas, values, and motivating the actions. Persuasion can be defined as a change in attitude through exposure to information obtained from other people. An attitude is selfassertiveness (Severin \& James, 2009: 177). Persuasion communication has an understanding that communication activities involve several people. The communication process is trying to tell and listen, but the communication process must contain various ideas, thoughts, facts, and opinions from one person to another. Through understanding, communication is an art of transmitting information from the communicator (messages, ideas, attitudes, ideas) to the communicant to change the form of behavior (patterns, attitudes, views, and understanding) to the customs and perceptions that the communicator wants (Romli, 2016: 7-8).

Through the blasphemy case during the election process for the governor of Jakarta, the wave of 
right populism gained momentum to be present in the public discourse. This wave is current in Indonesia using rhetoric that is similar to those in America or Europe. The rhetoric of right populism puts forward the jargon of "indigenous" and "antiforeigner."

After the "212" movement in Indonesia, identity politics has strengthened and formed mass mobilization, which is closely related to the identity of the majority religion in Indonesia. The term wave of right populism often interprets similar conditions. According to John B. Judis, populism is a way of thinking political logic and not an ideological movement. Judis added that if the proper populism movement is more triadic, besides exploiting the conflict between the people and the elites, they also accuse the elites of collaboration with third parties. The narrative is built that the third party is responsible for all the difficulties and difficulties of life experienced (Judis, 2016: 14).

These populist politicians can quickly enter and fill the anger. They target the existing minorities so that racism thrives and is supported by nativistic and tribalistic narratives. That is how the proper populism movement gets its movement in politics (IndoPROGRESS: 12.12.2017).

Cas Mudde (2007: 22-23) has explained the characteristics of populism which consist of three aspects: 1) Anti-establishment, which emphasizes philosophy on the values of wisdom and virtue of ordinary people or the silent majority who is opposed to the rulers. Populism reflects deep hatred for the rulers and ordinary people. Homogeneous parties are considered reasonable and deemed worthy of replacing the existing elite; 2) Authoritarianism supports the power from individuals considered worthy of leading the state or government in absolute terms; 3) Nativism, which defines all "people" as a unit with the same identity. Therefore, populism supports monoculturalism rather than multiculturalism within society.

The hallmark of Islamic populism is the political language of Islam. In short, the difference between conventional populism and Islamic populism is the basic concept of "The Peoples" as a people oppressed by an elite. In Islamic populism, the idea of "The Peoples" is replaced by an oppressed and marginalized ummah (Balairungpress: 27.08.2018). 


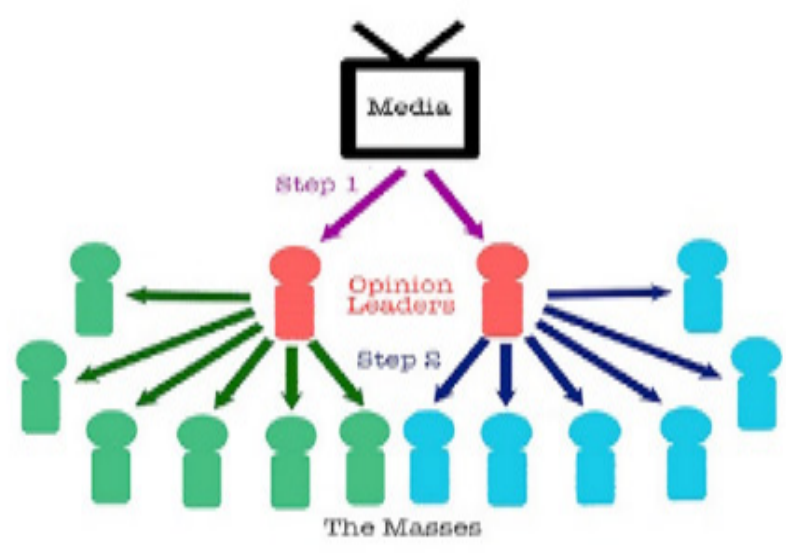

Figure 2. Lazarsfeld's two-stage communication process view (http://ilkom. unida.gontor.ac.id/teori-komunikasi-dua-tahap/)

Persuasion can be interpreted as an action by a persuader in carrying out changing persuadee attitudes. This action appears to provide information that influences the persuadee to alter perspective so that the interests of the persuader can be fulfilled. Not only that, but Devito (2009: 78-79) also explains that persuasion can identify an approach into three parts:

1. Logical Appeals, consisting of logic, ethics, and credibility, are practical tools for persuasion. Persuader will try to persuade or invite their listeners through philosophy, and the listeners will feel more comfortable and happier if influenced continuously;

2. Emotional Appeals, this is related to a level of need from the persuadee;
3. Credibility Appeals are a persuasion approach that emphasizes the role of a speaker or a resource person who is knowledgeable or competent in the language and topic and has good character and charisma. This credibility will hopefully influence the listeners in assessing a problem. A speaker or resource can have different credibility from one culture and another. In certain cultures, competence determines reliability. On the other hand, goodness and morality determine a reputation to measure one's credibility. Devito (2009: 80) summarized three points that become a determinant of accessibility, a) Competence, the more and in the knowledge 
and experience of the resource person or speaker or topic being presented, the listener will believe in what will be conveyed, including telling listeners what skills they have, then quoting some sources as reference materials, and the last is to use trusted sources by explaining their backgrounds and experiences; b) Character, when the listener can feel the good intentions of the speaker, the listener will give his trust. Several ways can improve moral character, including stress fairness from the speaker by emphasizing the situation by presenting both parties in the discussion. Secondly, the speaker stress concern for audiences; it aims to convince listeners. A speaker focuses on their welfare by giving interest but not exaggerating. The last one is stress concern for enduring. When a speaker is more interested in trivia issues, he becomes not credible compared to a speaker who brings broad or general topics; c) Charisma is one of the essential components for a speaker; the speaker can show the listener who will strengthen with charm. The recipients of this information will also give their trust. One way to increase their charisma can be done in several ways, such as providing a positive appearance, displaying enthusiasm, and empathy.

The Elaboration Likelihood Theory (ELT) model states that two routes can be traversed by messages during the persuasion process through the central and peripheral routes. Talking about this persuasion model, it works to determine changes in the attitude of the receiver, central and peripheral routes, has an effective persuasion technique but both ways. Each has its strategies and methods of getting effective persuasion action. This model talks about changing attitudes; it is necessary to consider mediating factors and the persuasion process. Therefore, the weight and number of messages related to cognitive responses, through an elaboration process that has conformity to the objects and information possessed by individuals, is an important step. The ELM process explains The Central Route and The Peripheral Route (Larson, 2010: 13): 1) The Central Route messages sent via the central route are straightforward and complete. There are various wise considerations of an idea in the main road, the opinion of the 
message content (Stephenson, Benoit \& Tschida: 2009, 324). The recipient of the message must have a caring attitude in receiving or understanding the message and evaluating the ideas in the content of the message. Since the notification sent via this route has a high level of involvement from the recipient, he must be correct and evaluate it; 2) The Peripheral Route can be successful if subjected to low message recipient involvement, poor message recipient motivation, and weak statements. Message recipients through the peripheral course are not processed cognitively. Thus, the message recipients conveyed through the peripheral route cannot broadly decipher the message. The message recipients can still be persuaded by several factors that have nothing to do with the actual content.

\section{RESULT AND DISCUSSION}

The Rise of Indonesian RightWing Populism Movement

The 212 group that mobilized the masses in this incident was not purely because of Ahok's blasphemy case but also other interests. As previously explained, Activities based on the ideology of populism exploit people's dissatisfaction with the elite, such as corruption, abuse of power, and so on, which stimulate the people's sentiment toward the ruling elite in Indonesia.

During the election, the wave of populism rouse because of the suspicion of the Indonesian elites. In particular, the doubt that the Indonesian government was antiIslamic (Ilahi, 2017). The 212 acts for defending the Koran are ultimately becoming symbolic actions for calling the people's solidarity to change the actual situation. This battle of defending Islam was gaining the attention of the Indonesian public nationally, wherein the development of this populism movement emphasized the issue of identity politics that brought the majority religion in Indonesia as the focus of struggle in political contestation (Mudde, 2007: 22).

Three factors cause the emergence of a wave of populism. They are the disappointment factor or, more precisely, the cognitive dissonance from several communities. The second is the emergence of political leaders with strong influence from marginalized communities (Since the New Order era, the Chinese community in Indonesia has had limited opportunities in political life in Indonesia). Lastly is the 
development of technology on social media.

Based on the causal factors conveyed, the wave of populism itself can be a political tool for both a group of people and a group of organizations and others that aim to take advantage of society through a dynamic and togetherness approach through a uniform religious identity. Based on this vantage point, the movement exploited the public disappointment with a thing used by a group of people, organizations, and others to form a mass base by using certain symbols and disseminated through various media. At this point, defending Islam aimed to enforce the law toward the blasphemer, where many Muslim communities in Indonesia offended.

Nonetheless, the 212-movement voiced to the public about the disappointment toward the Indonesian government as well. It means the objective of the campaign is broader beyond religious blasphemy into other political agendas. The narrative builds by the " 212 " movement shifted from defending religion into a protest to disappointment the current government. Especially to President Joko Widodo, he was protested by the masses for protecting blasphemers. They were using religious symbols, in this case, Islam, to strengthen the support of Indonesian people through various channels on social media such as Facebook, Twitter, and Instagram.

The wave of protests from the "212" movement voiced criticism that President Jokowi protected Ahok for his legal case. Responding to this incident, the government gave various rebuttals on the issue, stating legal protection for blasphemers. The government also explains that the problem is a legal issue, and the government has no interest in the case (Kompas: 8.11.2016). In understanding these dynamics, three aspects of classifying the wave of right populism, namely right populism, which occurs in a radicalistic nature or impact technology. The authors denote this populist movement corresponded with instrumentalists, radical and technological categories based on this classification. Significantly, the fact that a group's particular interests were using this momentum for fulfilling their political advantage. This post-"212" activity eventually became an instrumentalist moment for a group of people, organizations, mass organizations, and others to master the power material. Those symptoms came from various news 
reports, one of which is based on the opinion of Hendardi as Executive Director of the SETARA Institute. He assessed the 212-alumni reunion event as political movements. The continuity of this movement will become a new political arena that will continue to be political leverage against the Indonesian government. The target is to control the public space to increase their political bargaining power toward political groups.

\section{The Kemenko Polhukam RI's Per- suasion Approach}

Per its function, the Coordinating Ministry for Political, Legal, and Security Affairs (Kemenkopolhukam RI) can respond intelligently to dynamic environmental conditions that naturally grow, develop, and influence Indonesian society. Thus, the Kemenkopolhukam RI should overcome, coordinate, observe problems in the community due to the "212" actions. Therefore, they conducted a mass mapping of the " 212 " activity through classification, looking at the narrative presented and weighing the appropriate approach to the action.

To understand the political agenda of the " 212 " movement, The Kemenkopolhukam RI categorized the masses involved in "212" based on political aspirations. Based on their analysis, several groups are involved in this mass protest. The first are groups involved in the demonstrations because of their solid spiritual solidarity. Secondly, groups with particular political reasons delegitimize government power under President Joko Widodo's administration. The third is a group that seeks to change or replace the state ideology. The fourth is a group that uses the " 212 " actions as an electoral political vehicle. These four classifications are deduced by the Kemenkopolhukam $\mathrm{RI}$ related to the masses present at the "212" actions. According to their analysis, the largest group in this action wanted to delegitimize the Indonesian government through a series of actions and activities, and messages carried out by the " 212 " movement.

Then, after the Kemenkopolhukam RI conducted the grouping and saw the narratives developed by each cluster. They found that one of the narratives was developed by the " 212 " movement to label President Joko Widodo and Ahok as one group. Ahok's problem was President Joko Widodo's problem as the leader of this country. The narrative aimed to build public 
opinion that President Joko Widodo was the same as Ahok as an antiIslam. Ahok's supporters originally built the stamp of Ahok as a duality for President Joko Widodo. However, this narrative was exploited by groups that took advantage of the " 212 "-protest wave with electoral interests to attack President Joko Widodo. Attacking Ahok is tantamount to attacking Jokowi on the Indonesian political map. Therefore, getting rid of Ahok was the same as getting rid of Jokowi. The Coordinating Ministry for Political, Legal and Security Affairs tries to explain to the public that these two aspects are different. Even President Joko Widodo highlighted that the public should carefully perceive this discourse. As he conveyed directly, "Once again, the people also need to know, I will not protect Basuki Tjahaja Purnama because he has entered the legal process."

The Coordinating Ministry for Political, Legal, and Security Affairs delivered a counter-narrative to the public. This objective was achieved by filling public spaces with open dialogue activities, door stops, press conferences, and press releases, and then disseminated through traditional media. Understanding the public through representatives from the Coordinating
Ministry for Political, Legal, and Security Affairs explains the case. It is a strategic activity for balancing the existing narrative from antigovernment groups. In delivering its narrative message to the public, the Coordinating Ministry for Political, Legal, and Security Affairs does not do it alone. The Coordinating Ministry for Political, Legal and Security Affairs collaborates with other institutions to disseminate counter-narratives and understand. The Coordinating Ministry for Political, Legal and Security Affairs also asked for support and opinion from communities. The Coordinating Ministry for Political, Legal, and Security Affairs asked counsel from religious leaders such as NU and Muhammadiyah to convey messages to the public. In this case, Indonesian religious leaders' support from a significant Muslim organization can calm the public opinion.

Counter-narrative is not the only persuasive approach taken by the Coordinating Ministry for Political, Legal, and Security Affairs. The Coordinating Ministry also used another method for Political, Legal, and Security Affairs to understand the community, one of which was to gather Ulama and similar leaders of community organizations. Besides, after grouping the "212" 
masses, the Coordinating Ministry for Political, Legal, and Security Affairs analyzed the narratives presented and prepared counternarratives to balance the description circulating in the community against the government. The Coordinating Ministry for Political, Legal, and Security Affairs also approached religious leaders and mass organizations to aim that the messages or narratives conveyed by the Coordinating Ministry for Political, Legal, and Security Affairs for the community were more understood and accepted.

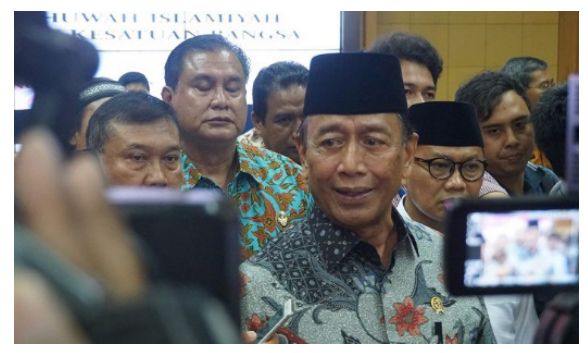

Figure 3. Coordinating Minister for Political, Legal and Security Affairs Wiranto (2016-2019) who gave press statements after meetings with religious leaders (https://polkam. go.id/dialog-bersama-tokoh-islammenko-polhukam-ajak-seluruhumat-sama-sama-jaga-stabillitaskeamanan/)

The Coordinating Ministry for Political, Legal, and Security Affairs also held a closed meeting by inviting several leaders of Islamic community organizations (mass organizations) such as the Nahdlatul Ulama Board (PBNU), the Indonesian Ulema Council (MUI), the Islamic Association (Persis), GNPF Ulama. The "212" Alumni Presidium and the Minister of Religion Lukman Hakim Saifuddin also attended this discussion. The national dialogue with the theme "With the Spirit of Ukhuwah Islamiyah, We Maintain National Unity and Unity." Coordinating Minister for Political, Law, and Security Affairs Wiranto said that the event aimed to strengthen togetherness to maintain the country's stability.

A person's reaction to news conveyed by a media is mediated by interpersonal communication with members of their social environment. Membership of a person in different social groups (family, friends, religion, etc.) dramatically influences the decision-making process and the person's behavior (Monica: 2014). Observe the Coordinating Ministry for Political, Legal, and Security Affairs efforts to approach key people or take the anchor approach. This approach is following the twostep communication process (twostep flow communication model) conveyed by Lazarsfeld, and the following is a scheme described 
by the Communication Process of the Coordinating Ministry for and community or community organizations: Political, Legal, and Security Affairs with the approach of crucial people

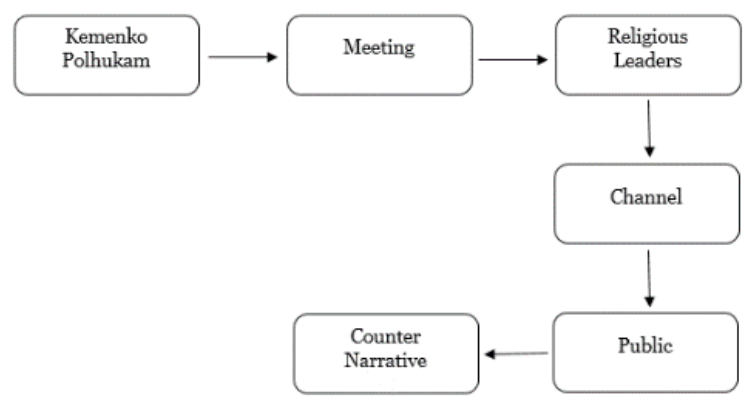

Figure 4. Schematic view of the message process from the data processed by researchers.

The way the government delivers messages to the public is through the approach of crucial people, the anchor approach to critical figures, coordination between governments and figures, especially in the " 212 " movement is Muslim figures. Coordination with religious leaders was implemented through intergovernmental meetings with religious leaders; the dialogue between the Coordinating Ministry for Political and Security Affairs and religious leaders brought the core message to the community. Furthermore, religious leaders will assist the Coordinating Ministry for Political, Legal, and Security Affairs to spread the message to the public through several activities such as lectures, facilitated dialogue, and social media. This theory works by influencing public decisionmaking through opinion. Two-step flows work through intermediaries introduced to the audience, the step of disseminating information through influential figures or opinion leaders with greater access to information than many audiences, they (opinion leaders) have the authority to explain and dissect the message, thus affecting the final opinion of the recipient who made contact with opinion leaders (Amy: 2016)

In this study, the Coordinating Ministry for Political, Legal, and Security Affairs influenced people's beliefs by motivating them to widely and deeply examine the messages in the news. Through democracy, the 
people will help spread the correct issue and remind others to be careful with hoaxes based on Richard Petty and John Cacioppo's persuasion model using the Elaboration Likelihood Theory (ELT) technique. The ELT theory explains two ways that a person evaluates information; firstly, carrying information through the central path, meaning in a complicated way using critical thinking. Secondly, the persuasion message was carried over through the peripheral route, meaning that the recipient does not always use the essential path to get the news. Sometimes information is evaluated thoroughly or uses less critical thinking (Morissan, 2013: 84).

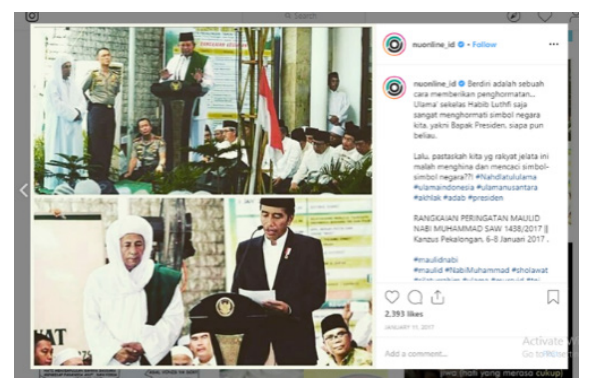

Figure 5. A form of persuasion message shown by Nahdlatul Ulama (https://www.instagram.com/p/BP HYFOZD7qX/?igshid $=135 \mathrm{dq} 3 \mathrm{w} 7 \mathrm{p}$ rvgn)

Every individual has the right attitude in the conditions at hand. Still, the individual will try to rationalize the constraints faced, and a strong argument will always succeed in giving a deep impression in the minds of the public (Primadhany: 2016, 6). Theoretically, ELT has two ways how individuals receive and manage a message. The peripheral route is a state of attitude change for a while. The central route is a state of attitude change. In this case, they will actively think about the information and consider other information that has been digested beforehand. Suppose, in the end, the recipient of the message shifts, and the result will be more permanent and be followed by a behavior change. At the same time, the peripheral route is the cognitive tendency of receiving and rejecting a message. In that case, this situation is based on the credibility of the message sender, environmental reactions, or being affected by several other factors beyond argumentation (Petty \& Cacioppo, 1996: 87).

The Coordinating Ministry for Political, Legal, and Security Affairs spread its persuasion message utilized all channels, such as dialogue on TV, direct approach to crucial people, sense of community, and technology. The key people here are people or figures who can influence the thinking of many people. Through a community, the 
approach is also an important step to be implemented, and through social media to spread the message of persuasion massively. As a note of sustainability in maintaining the influence, Kemenko Polhukam has to keep a report to the public and political parties, mass organizations, and the media. That communication approach is essential to deliver the message to foster respect for all people, not only for one group and organization but also to develop respect for all citizens so that a mutual understanding will fly due to this respect. Political literacy and media literacy are essential to protect people from being exploited for political interest. To make people understand the issue, it also relies on people's capability for digesting messages, the social responsibility of parties that cannot quickly spark public reactions with existing religious issues for political gain. Finally, persuasion messages for the news media, both tv, newspapers, and radio, promptly raise and lower populist points that stimulate conflict due to religious issues.

The central route is an individual condition when doing elaboration or critical thinking. Each individual manages a message through stimulation of information and will discuss it into the mind, choose, consider each absorption of the news. Whereas in the peripheral route, information management becomes less critical, where the changes that occur at the message recipient do not last long or are only temporary (Petty \& Cacioppo, 1986: 1-24). One of the ways used in this case is by using events and influencers to convey their persuasive message. The two strategies use easy language, a more down-to-earth language according to everyday life. Therefore, the recipient does not need to explore the news extensively, so there are not too many arguments.

According to Richard Petty and John Cacioppo, Indonesians mostly manage messages through these two routes based on the two lines of receiving persuasion messages. Each individual will listen to or sort any information or messages provided. In managing these messages, they will also listen to suggestions or other opinions through people they trust or have credibility with discussing the news. Thus the process of receiving messages through the Central Route and Peripheral Route. This tendency determines through the motivation shown by the community to find out information through various media; 
we can see this tendency through the following factors:

1. The relevance shown through the 212 actions is religion. There is blasphemy against the faith of most of the population in Indonesia, namely Islam, causing sentiment and anger, which ultimately attracts a lot of public attention.

2. Critical discourse spreads through various arguments in society through news coverage, public discussions, and expert analysis published in multiple media types. The amount of information or messages in the public space regarding this matter does not make the government limit the current news. The government also carries out various counternarratives to provide counternarratives to the public through crucial figures such as scholars and religious organizations. The diversity of arguments in the public space is one of the critical thinking tools in society in managing information because this diversity of information or messages can ultimately be compared.

3. Through an abundance of information or messages, the public can weigh and observe various existing news so that the argumentative and critical nature of the public emerges as an effect of the data.

The Coordinating Ministry for Political, Legal, and Security Affairs has high motivational abilities and understands or knows the information managed in dealing with this case. Therefore, the efforts of persuasion by the Coordinating Ministry for Political, Legal, and Security Affairs to the community accepted through a central channel. Based on how the government (Kemenko Polhukam) fills the public space with various messages, the government carries out various activities to meet the public's information needs by balancing the narrative built by antigovernment groups in this wave of right populism. Every single step to weather the mass protest was essential for protecting the security and stability of Indonesia.

\section{CONCLUSION}

At this point, this article concludes that religion as a bargaining power for the benefit of a few people in politics is inevitable. Religion makes this movement a right populism, but which leads to a form of Islamic populism. The hallmark of Islamic populism 
is its political language that uses symbols, discourse, and narratives from religion, in this case, Islam. Meanwhile, the difference between conventional populism with Islamic populism lies in the basic concept of "The People" by those movements.

Based on the analysis, the rise of Islamic populism in Indonesian society after the " 212 " action required the government to respond strategically to manage the issue through persuasion, where the government, in this case, the Kemenkopolhukam RI, used a persuasion approach by selecting key figures or religious leaders. Religious leaders will convey the message to the public through the way it chooses to form a counternarrative. They tried to influence people's beliefs by motivating them to examine the statements in the news widely and deeply. The variety of narratives and arguments related to the "212" action led communicants to shape attitudes and how these attitudes changed. The Kemenko Polhukam RI filled the public space with various messages that counter the narrative build by the rightwing populism movement. It was crucial to balance the narrative built by anti-government groups in this wave of right populism.

\section{BIBLIOGRAPHY}

Book

Devito, J. (2009). Eleventh Edition Human Communication, The Basic Course. USA: Pearson Education, Inc.

Hadiz, V. R. (2016). Islamic Populism in Indonesia and The Middle. Cambridge: Cambridge University Press.

Hastings, M., Durant , I., CohnBendit, D., Hirs , M., Schwan , G., De Waele , J.-M., . . Papp, T. (2013). The Rise of Populism and Extremist Parties in Europe. Brussels: The Spinelli Group.

Judis, J. B. (2016). The Populist Explosion. How the Great Recession Transformed American and European Politics. New York: Columbia Global Report.

Larson, C. (2010). Persuasion: Reception and Responsibility (Twelfth Editon ed.). Boston, MA: Cengange Learning.

Morissan. (2013). Teori Komunikasi: Individu Hingga Massa. Jakarta: Prenadamedia Group.

Mudde, C. (2007). Populist Radical Right Parties in Europe. New York: Cambridge University Press. Muhtadi, B. (2019). Populisme Politik Identitas dan Dinamika Elektoral. Malang: Intrans Publishing. 
Petty, R. E., \& Cacioppo, J.T. (1986). The Elaboration Likelihood Model of Persuasion, in Communication and Persuasion, New York, NY: Springer New York.

Petty, R. E., \& Cacioppo, J.T. (1996). Attitudes and persuasion: Classic and contemporary approaches, Colorado: Westview Press.

Romli, K. (2016). Komunikasi Massa. Jakarta: PT Grasindo. Diperoleh dari https://books. google.co.id/books?id=DsR GDwAAQBAJ\&printsec $=$ fr ontcover $\&$ hl $=i d \&$ source $=g$ bs_ge_summary_r \&cad $=0$ $\# \mathrm{v}=$ onepage $\& \mathrm{q}=\operatorname{model} \% 20$ komunikasi\&f=false

Severin, W. J., \& James, W. T. (2009). Teori Komunikasi: Sejarah, Metode, dan Terapan di Dalam Media Massa (4th ed.). Jakarta: Kencana Prenada Media Group. Yin, R. K. (2009). Case Study Research: Design and Methods. California: SAGE Publications, Inc.

\section{Journal}

Benoit, W. L., Stephenson, M. T., \& Tschida, D. A.. (2009). Testing the mediating role of cognitive responses in the elaboration likelihood model. Source: Communication Studies, Vol.52,
No. 4, (Autumn, 2001), pp. 324.

Published by: Routledge.

Kusumo, R., \& Hurriyah. (2018). Populisme islam di Indonesia: Studi Kasus Aksi Bela Islam Oleh GNPF-MUI 2016-2017. Source: Jurnal Politik, Vol. 4, No. 1, pp. 87-109. Published by: FISIP Departmen Ilmu Politik Univetsitas Indonesia.

Primadhany Kartana Putri. (2016). Aplikasi PendekatanPendekatan Persuasif Pada Riset Komunikasi Pemasaran: Iklan Melibatkan Penciptaan dan Penerimaan Pesan Komunikasi Persuasif Mengubah Perilaku Pembelian. Source: THE MESSENGER, Vol 8, No. 1, pp. 87-109. Published by: Departmen of Communication, Information and Communication Technology Faculty, Universitas Semarang.

\section{Website}

Affan, Heyder. (2016). "Aksi 212: Usai Jokowi bicara Rizieq Shihab langsung serukan tangkap Ahok".BBC Indonesia 2 December 2016. (accessed on 15 September 2020). Retrieved from https://www.bbc.com/ indonesia/indonesia-38178840 Agustin, Dwina. (2017). "Ini 7 Rangkaian Aksi Bela Islam 
Sebelum Ahok Divonis 2 Tahun Penjara”. Naional Republika 10 May 2017. (accessed on 15 September 2020). Retrieved from https:// nasional.republika.co.id/berita/ nasional/hukum/17/05/10/ opp5r4330-ini-7-rangkaianaksi-bela-islam-sebelum-ahokdivonis-2-tahun-penjara-part1

Artharini, Isyana. (2016). "Aksi demo 411, 212, dan 'efek trauma' yang membayangi pengusaha”. BBC Indonesia 1 December 2016. (accessed on 15 September 2020). Retrieved from https://www.bbc.com/ indonesia/indonesia-38157870

Ihsanuddin. (2016). "Jokowi: Saya Tidak Akan Lindungi Basuki Tjahaja Purnama”. Kompas 08 November 2016. (accessed on 15 September 2020). Retrieved from https:// nasional.kompas.com/ $\mathrm{read} / 2016 / 11 / 08 / 11370021 /$ jokowi.saya.tidak.akan. lindungi.basuki.tjahaja. purnama

Nadzir, Ibnu. (2019). "Prabowo dan Bangkitnya Populisme Sayap Kanan di Indonesia”. Tirto 27 February 2019. (accessed on 15 September 2020). Retrieved from https://tirto.id/prabowodan-bangkitnya-populisme- sayap-kanan-di-indonesiadhLf

Pane, Beby. (2018). "Vedi Hadiz: Kuasa Oligarki Dilanggengkan lewat Populisme Islam". Balairung press 27 August 2018. (accessed on 15 September 2020). Retrieved from https://www.balairungpress. com/2018/08/19211/

Postelnicu, Monica. (2014). “Twostep flow model of communication," Britannica, March 15, 2014. (accessed on September 30, 2020). Retrieved from https://www.britannica. com/topic/two-step-flowmodel-of-communication

Supriatma, Made. (2017). "Pasang Naik Populisme Kanan?”. Indo Progress December 12, 2017. (accessed on September 15, 2020). Retrieved from https:// indoprogress.com/2017/12/ pasang-naik-populisme-kanan/

\section{Research Paper}

Inglehart, R. F., \& Norris, P. (2016). Trump, Brexit, and the Rise of Populism: Economic Have-Nots and Cultural Backlash. HKS Working Paper No. RWP16026. (accessed on September 30, 2020). Retrieved from https:// papers.ssrn.com/sol3/papers. cfm?abstract_id=2818659 